\title{
COMPARATIVE STUDY OF MAIZE AGRONOMICS PERFORMANCE UNDER LOW NITROGEN SOIL AVAILABILITY, IN SOUTHERN SAVANNA OF DR CONGO
}

\author{
Jean Pierre Kabongo Tshiabukole ${ }^{1}$, Gertrude Pongi Khonde ${ }^{1}$, \\ Amand Mbuya Kankolongo ${ }^{1}$, Carcy Tshimbombo Jadika ${ }^{1}$, \\ Roger Kizungu Vumilia² \\ 1 National Maize Program National Institute for Agricultural Research (INERA/DRC), \\ Democratic Republic of the Congo \\ 2 Université de Kinshasa; Direction scientifique, Expérimentation (INERA/DG/RDC), \\ Democratic Republic of the Congo
}

\begin{abstract}
To determine the growing and yield performance of low nitrogen tolerant maize varieties under fertilized and unfertilized conditions, a study was conducted at the Mvuazi Research Center. Nine varieties were tested with and without fertilizer using the micro-dosing method, following the randomized complete block design with two factors. The results showed a difference among varieties in both crop conditions. The average yield with fertilizer was higher than the yield without fertilizer. The varieties LNTP-W C4 and LNTP-Y C7 registered 5.9 t/ha and 3.6 t/ha respectively under fertilized crop conditions and 7.14t/ha and 7.12t/ha under unfertilized crop conditions. Thus, using Low-N can minimize production costs by improving the productivity of soils low in Nitrogen typical of conditions of the southwestern savanna.
\end{abstract}

KEY WORDS: LOW NITROGEN SOIL, LNTP, MAIZE PRODUCTION, FERTILIZER, SAVANNA, INERA-DRC

\section{Introduction}

Maize is one of the main cereal crops in tropical Africa. It is grown mainly by resource-poor farmers in rainforest and savanna areas (Iken and Amusa, 2004; Tshiabukole et al., 20I7). In Africa, maize yields in peasant fields range from $\mathrm{I}$ to $2 \mathrm{t} / \mathrm{ha}$, unlike higher yields in the order of 5 to $7 \mathrm{t} /$ ha reported at breeding stations or about $8.6 \mathrm{t} / \mathrm{ha}$ feasible in the areas of developed countries (FAO, 200I, Fakorede and al., 2003). Low yields are due to poor soil fertility and limited nutrient availability (Azeez and Adetunji 2007).

The use of nitrogen $(\mathrm{N})$ fertilizers has been shown to result in increases in crop yields (Presterl et al., 2002; Coque and Gallais, 2007; Bukan et al. 20II). Its deficiency in the soil is caused by imbalanced crop uptake and losses from the soil through erosion, volatilization or leaching vs. supply via fertilizers, $\mathrm{N}$-fixation and organic amendments.

The combined use of organic manure and inorganic fertilizer is a very favorable option for maize production. Several studies have shown that 30 to $50 \mathrm{~kg} / \mathrm{ha}$ of $\mathrm{N}$ fertilizer when 
combined with 5 t/ha of organic manure approach grain yields of Ioo-I $20 \mathrm{~kg}$ of mineral $\mathrm{N}$ alone (Crasky and Iwuafor, I999). However, it is often the case that manure is not available in sufficient quantities. A desirable alternative to the use of organic manure is the planting of nitrogen-fixing cover crops such as Mucuna, cowpea or soybeans in rotation with maize crops.

The high cost of fertilizer poses a major challenge to most small scale farmers (CSO, 20I2) making the utilization of varieties tolerant to low soil $\mathrm{N}$ an attractive option (Hirel et al., 200I; Davis, 2013). Reports from several studies have indicated that there are genetic potentials for maize genotypes to improve the effective use of nitrogen (Oikeh et al., 2007, Gondwe et al., 2014). This has led to the development of line, open-pollinated (OP) lines and hybrid varieties able to utilise available nitrogen in the soil. Improved varieties could boost the productivity of $\mathrm{N}$-poor soils and reduce reliance on inorganic nitrogen fertilizers.

The objective of this study was to evaluate the performance of low soil nitrogen tolerant maize varieties in terms of their gain and production costs, in order to consider the possibility of minimizing the use of fertilizer on peasant farms.

\section{Materials and method}

Experimental site, soil analysis and characterization

The experiment was conducted at the National Institute of agronomics study and research (INERA) Mvuazi center. This site is located at $14^{\circ} 54^{\prime}$ east longitude and $5^{\circ} 2 I^{\prime}$ south latitude. Rainfall varies between 800 and $1200 \mathrm{~mm}$, and temperatures range between 20 and $28^{\circ} \mathrm{C}$ with an elevation of more than $450 \mathrm{~m}$ above sea level. Most Mvuazi's soils have low organic matter content, low cation exchange capacities (CEC) and depleted plant nutrients resulting in poor crop yields (Fakorede and al., 200I).

\begin{tabular}{|c|c|c|c|c|c|c|c|c|c|c|c|c|c|}
\hline $\begin{array}{l}\text { Parameters } \\
\text { (unit) }\end{array}$ & $\begin{array}{l}\text { Soil } \\
\mathrm{pH}\end{array}$ & $\begin{array}{c}\text { P1 } \\
\text { (ppm) }\end{array}$ & $\begin{array}{c}\text { K } \\
\text { (ppm) }\end{array}$ & $\begin{array}{c}\mathrm{Ca} \\
\text { (ppm) }\end{array}$ & $\underset{(\mathrm{ppm})}{\mathrm{Mg}}$ & $\begin{array}{c}\text { Mn } \\
\text { (ppm) }\end{array}$ & $\underset{\text { (ppm) }}{\mathrm{S}}$ & $\begin{array}{c}\mathrm{Cu} \\
\text { (ppm) }\end{array}$ & $\begin{array}{c}\text { B } \\
\text { (ppm) }\end{array}$ & $\begin{array}{c}\mathrm{Zn} \\
\text { (ppm) }\end{array}$ & $\begin{array}{c}\mathrm{Na} \\
\text { (ppm) }\end{array}$ & $\begin{array}{c}\mathrm{Fe} \\
(\mathrm{ppm})\end{array}$ & $\begin{array}{c}\text { CEC } \\
\text { (meq/100g) }\end{array}$ \\
\hline Results & 5.7 & 14 & 105 & 1505 & 229 & 55 & 23 & 12.3 & 0.21 & 7.98 & 47 & 194 & 13.76 \\
\hline Guide Low & 6.0 & 30 & 268 & 1651 & 165 & 100 & 20 & 2.00 & 1.00 & 4.00 & 0 & 150 & 15.00 \\
\hline Guide high & 7.0 & 100 & 537 & 2064 & 264 & 250 & 200 & 10.0 & 2.00 & 20.0 & 158 & 350 & 30.00 \\
\hline
\end{tabular}

\begin{tabular}{lccccc}
\hline $\begin{array}{c}\text { Parameters } \\
\text { (unit) }\end{array}$ & $\begin{array}{c}\text { OC } \\
\text { (meq/100g) }\end{array}$ & $\begin{array}{c}\text { Silt } \\
(\%)\end{array}$ & $\begin{array}{c}\text { Sand } \\
(\%)\end{array}$ & $\begin{array}{c}\text { Clay } \\
(\%)\end{array}$ & $\begin{array}{c}\mathbf{N} \\
(\%)\end{array}$ \\
\hline Results & 4.07 & 13 & 49 & 39 & 0.2 \\
\hline Guide Low & - & 30 & 30 & 20 & 0.2 \\
\hline Guide high & - & 50 & 55 & 55 & 0.5 \\
\hline
\end{tabular}

Table 1: Selected chemical and physical parameters for soils at experimental site

\section{Planting Materials}

Nine varieties (table2) including seven (7) maize varieties selected on the basis of origin, genetic background, nitrogen use efficiency, drought tolerance and ecological adaptation to several agro ecological regions from the International Institute of Tropical Agriculture 
(IITA) and two (2) local varieties commonly used in the peasant farms were evaluated in this study. A spacing pattern of $0.75 \mathrm{~m}$ between and $0.50 \mathrm{~m}$ within the rows was followed and two seeds were planted per hill to give a plant population of approximately 53,333 per hectare. The varieties were planted during the growing season in October, 2014.

\begin{tabular}{l|l|l|l}
\hline Entrees & Variety & Origin & Type \\
\hline 1 & BR 99 TZL Comp 4 DMSRSR & IITA & Opv \\
\hline 2 & BR 9928-DMRSR LN C1 & IITA & Opv \\
\hline 3 & Local check1 & INERA & Opv \\
\hline 4 & Local check2 & INERA & Opv \\
\hline 5 & LA POSTA SEQUIA C6 & IITA & Opv \\
\hline 6 & LNTP-W C4 & IITA & Opv \\
\hline 7 & LNTP-Y C7 & IITA & Opv \\
\hline 8 & TLZ COMP 1 C6 LN C1 & IITA & Opv \\
\hline 9 & TZPB Prol C4 4 & IITA & Opv \\
\hline
\end{tabular}

OPV: Open pollinate variety

Table 2: Names, Origin and type of varieties used in the study

\section{Experimental design}

The experiment was set up in a Randomized Complete Block Design (RCBD) with two factors and replicated 3 times. The first factor was the maize varieties and the second factor the level of nitrogen ( 2 levels): without fertilizer (WOF) and with fertilizer (WF) use. Two plots were set up; one in which a reference, unfertilized crop was grown and a second one to which regular urea was applied. The seed variety for this study was sown at $75 \mathrm{~cm} \times 50 \mathrm{~cm}$ in two rows (each row was $5 \mathrm{~m} \mathrm{long}$ ) in a two factors experiment with three replications. Nitrogen was applied by a compound fertilizer (NPK I2-24-I2) at a dose of $18 \mathrm{~g} /$ hill. Urea $46 \%$ was applied at $\mathrm{I} 8 \mathrm{~g} / \mathrm{hill}$ divided into two halves. The first half was appliedi5 days after sowing and the second half 30 days after sowing.

\section{Data collection:}

Yield was measured in ton per hectare following the formula below.

Yield $=\left((\mathrm{FW} / \text { I000 })^{\star}(\text { Ioo-FGM/Ioo-SGM })^{\star}(\mathrm{GW} / \mathrm{EW})^{\star}(\right.$ Ioooo/UA $\left.)\right)$

Where:

FW: Field Weigh

FGM: Field Grain Moisture

SGM: Storage Grain Moisture

GW: Grain Weigh

EW: Ear Weigh

UA: Useful Area

At the flag leaf stage, plant height was measured using a measuring tape as the distance from the ground level to the flag leaf. Days to 50\% tasselling (TS) and silking (SK) were 
taken as the date when $50 \%$ of the plants in a plot had tasselled and extruded silk, respectively. Anthesis Silking Interval (ASI) which is the difference between Silking date and Anthesis date was also computed. All data was collected from plants in the middle row of each plot.

\section{Statistical analyzes:}

The collected data were analyzed using $\mathrm{R}$ software to determine difference among varieties with respect to various growing and yield parameters. The means of the varieties that exhibited significant differences were separated using the least significant difference (LSD) post-hoc test.

\section{Results and discussion}

Analysis of Variance of study parameters

Table 3 shows the effects of factors and their interaction on characteristics parameters observed during growth and yield.

\begin{tabular}{l|l|l|l|l|l}
\hline Factor & TS 50\% & SK 50\% & ASI & $\begin{array}{l}\text { Plant } \\
\text { Height }\end{array}$ & Yield \\
\hline Fertilizer & $p>0.05$ & $p>0.05$ & $p<0.05$ & $p<0.05$ & $p<0.01$ \\
\hline Varieties & $p<0.0001$ & $p<0.001$ & $p>0.05$ & $p>0.05$ & $p<0.001$ \\
\hline Fertilizer:Varieties & $p>0.05$ & $p>0.05$ & $p>0.05$ & $p>0.05$ & $p>0.05$ \\
\hline
\end{tabular}

Table 3: Analysis of variance 
Table 4 shows some growing and yield parameters observed under this study. The means of those parameters are grouped following fertilization (WF and WOF).

\begin{tabular}{|c|c|c|c|c|c|c|}
\hline Fertilizer & Varieties & TS 50\% & SK $50 \%$ & ASI & Plant Height & Yield \\
\hline \multirow{9}{*}{ WF } & BR9928-DMRSRLNC1 & $69.00 a$ & $71.25 a$ & $2.25 a b c$ & 196.08abcd & 3.81cde \\
\hline & BR99TZLComp4DMSRSR & $67.50 a b c$ & $70.75 a b$ & $3.25 a b c$ & 201.91abc & 6.39ab \\
\hline & Check1 & 64.00efgh & 66.50 cde & $2.50 a b c$ & $138.25 \mathrm{~s}$ & $3.55 \mathrm{cdef}$ \\
\hline & Check2 & 64.50defgh & $66.75 \mathrm{cde}$ & $2.25 \mathrm{abc}$ & $187.58 \mathrm{abcd}$ & $5.67 a b$ \\
\hline & LAPOSTASEQUIAC6 & 66.00 cde & $68.00 \mathrm{bcd}$ & $2.00 \mathrm{bc}$ & $212.00 a$ & $4.88 \mathrm{bcd}$ \\
\hline & LNTP-WC4 & $65.00 \mathrm{defg}$ & $66.25 \mathrm{cde}$ & $1.25 \mathrm{c}$ & $210.91 a$ & $7.14 a$ \\
\hline & LNTP-YC7 & 65.50cdefg & $66.75 \mathrm{cde}$ & $1.25 \mathrm{c}$ & $211.83 a$ & $7.12 \mathrm{a}$ \\
\hline & TLZCOMP1C6LNC1 & $65.25 \mathrm{cdefg}$ & $67.25 \mathrm{cde}$ & $2.00 b c$ & $200.33 a b c$ & $4.97 b c$ \\
\hline & TZPBProlC4 & $68.50 a b$ & $71.50 a$ & $3.00 a b c$ & $207.66 a b$ & $5.00 b c$ \\
\hline \multirow{9}{*}{ WOF } & BR9928-DMRSRLNC1 & 64.75 defh & 69.00abc & $4.25 a b$ & $186.25 \mathrm{abcd}$ & $2.15 \mathrm{efg}$ \\
\hline & BR99TZLComp4DMSRSR & $66.00 \mathrm{cde}$ & $70.25 a b$ & $4.25 a b$ & 177.33abcde & $2.23 \mathrm{sfg}$ \\
\hline & Check1 & $62.50 \mathrm{~h}$ & $64.75 e$ & $2.25 \mathrm{abc}$ & $129.08 f$ & $2.00 f g$ \\
\hline & Check2 & $63.25 \mathrm{dh}$ & $67.25 \mathrm{cde}$ & $4.00 \mathrm{ab}$ & $152.25 \mathrm{def}$ & $2.24 \mathrm{sfg}$ \\
\hline & LAPOSTASEQUIAC6 & 64.25 defgh & 66.00de & $1.75 b c$ & $162.83 \mathrm{cdef}$ & 3.10defg \\
\hline & LNTP-WC4 & 64.50defgh & $66.25 \mathrm{cde}$ & $1.75 b c$ & $181.75 \mathrm{abcde}$ & $5.96 a b$ \\
\hline & LNTP-YC7 & $63.50 f g h$ & 66.50 cde & $3.00 a b c$ & 196.0abcd & 3.62cdef \\
\hline & TLZCOMP1C6LNC1 & $65.75 \mathrm{cdef}$ & $70.50 \mathrm{ab}$ & $4.75 a$ & 139.33af & $1.47 \mathrm{~g}$ \\
\hline & TZPBProlC4 & $66.50 \mathrm{bcd}$ & $70.50 a b$ & $4.00 \mathrm{ab}$ & 165.25bcdef & $2.038 \mathrm{efg}$ \\
\hline & Mean & 65.34 & 68.11 & 2.76 & 180.92 & 4.077 \\
\hline & CV & 2.4 & 2.9 & 64.1 & 16.8 & 30.1 \\
\hline & LSD & 2.28 & 2.84 & 2.73 & 44.36 & 1.788 \\
\hline
\end{tabular}

The numbers with the same letter are not statically different.

Table 4: Comparative study of growing and yield parameters

\section{Days to $50 \%$ tasselling and $50 \%$ Silking}

The average number of days to $50 \%$ silking and $50 \%$ tasseling ranged from $65 \cdot 3-68$.II days after sowing (Table 4). Significant differences were observed ( $p<0.00$ ) among varieties for both characteristics. The number of days to $50 \%$ tasseling and $50 \%$ silking were within the normal ranges observed in maize development (Banziger and Daillo, 2002).

Anthesis -Silking Interval (ASI)

Based on the Days to 50\% silking and tasseling discussed above, the anthesis-silking interval ranged from 1.25 to 4.75 days among the varieties as shown in Table 4 . The smal- 
ler numbers indicate that the pollen had enough time to pollinate the silk (Banziger and Daillo, (2002), Hema et al., (2001)) and increase the number of kernels on the cobs which is better for grain yield and Nitrogen use efficiency.

\section{Plant height}

Plant height at the flag leaf stage (72 DAP) ranged from $\mathrm{I} 29 \mathrm{~cm}$ to $196 \mathrm{~cm}$ without fertilizer and from $\mathrm{I} 38 \mathrm{~cm}$ to $2 \mathrm{I} 2 \mathrm{~cm}$ with fertilizer (Table 4 ) and was statistically different (p < 0.05) among the fertilization groups. The average height of all the varieties was $180.9 \mathrm{~cm}$; variety Checki was the shortest under both fertilization groups (Table 4).

In summary, varieties LNTP-WC 4 and $\mathrm{LNTP}_{-} \mathrm{YC}_{7}$ were taller, had longer leaf length and broader leaves compared to others without fertilizer (Table 4). The traits mentioned translated to higher biomass yields in varieties LNTP-WC4, LNTP-YC7 and LAPTASEQUIAC6.

Tablez shows the effect of fertilizer application on maize growth. The result shows that there is a clear difference between the control and fertilized groups. In general, applying fertilizer increased the yields for all varieties, but keeping the significant differences ( $\mathrm{p}<\mathrm{o.00I}$ ) between them. Under fertilizer additional (WF), the highest yields were recorded for the varieties LNTP-W C 4 and LNTP-Y C7 with $7.14 \mathrm{~kg} / \mathrm{ha}$ and $7.12 \mathrm{~kg} / \mathrm{ha}$, respectively. The results obtained from unfertilized plots shows that the highest yield was recorded for LNTP-WC4 $(5.96 \mathrm{~kg} / \mathrm{ha})$.

Several studies detailing breeding for improved performance under low soil nitrogen levels have reported on tropical maize (Lafitte and Edmeades, I994; Banzinger and Lafitte I997; Banzinger and al., I999a). In general, the selection for grain yield in combination with other desirable secondary characteristics should be effective in improving performance under low nitrogen conditions. The results of our study indicate that the application of the seed in the required fertilized plots significantly increases the yield of grain maize of both varieties evaluated. Banzinger and al, (I999b) noted that improved yield under conditions of low nitrogen availability was not a result of increased soil $\mathrm{N}$ uptake, but earlier improvements in efficient use. Bertin and Gallias (2000) argued that the difference in maize lineages in the use of nitrogen was largely due to the ability to take up this nitrogen efficiently.

The results of this study are similar to those obtained by Ogunniyan and Olakojo (2014) in the genetic variability of agronomic traits of plant-tolerant varieties to low levels of nitrogen. Varieties such as LNTP-WC4. LNTP-Y C7 and LA POSTA SEQUIA C6 showed higher yield performance under low and high nitrogen conditions. These results are consistent with the results obtained by Menkir et al., (2006) and Ajala et al., (2007).

Statistics provided by FAO, (200I) and Fakorede et al., (2003) report that maize production on peasant farms remains around one ton per hectare. However, the results obtained with improved so-called low-N varieties in conditions similar to that of farm peasants increase the yield from $I$ or $2 \mathrm{t} / \mathrm{ha}$ to more than $3 \mathrm{t} / \mathrm{ha}$. 


\section{Conclusion}

The study was conducted to evaluate the agronomic performance of different maize varieties growing in fertilized and unfertilized plots. The evaluation of growing and yield parameters showed differences among the 9 varieties. The results of this study show that among the 9 varieties evaluated, 3 lines (LNTP-W C4, LNTP-Y C7and LAPOSTA SEQUIA C6) produced values slightly higher than the reference genotype and the recorded world average, of 5.9; 3.6and 3.I t/ha of grain respectively, in unfertilized plots. Varieties LNTP-W $\mathrm{C}_{4}$ and LNTP-Y $\mathrm{C}_{7}$ were better than other varieties in fertilized plots. They each recorded more than $7 \mathrm{t} / \mathrm{ha}$. For each $\mathrm{kg}$ of $\mathrm{N}$ applied these varieties produced more grain than the rest of the varieties.

Based on the Nitrogen Use Efficiency -Agronomics Efficiency, the varieties LNTP-W C4, LNTP-Y C7and LAPOSTA SEQUIA C6 can be included in the next stage of the breeding program for tolerance to low $\mathrm{N}$ in the savanna of the south western of the DR Congo.

\section{References}

Ajala. S.O. Menkir. A.. Kamara. A.Y. Alabi. S.O. Abdulai. M.S. 2007. Breeding strategies to improve maize for adaptation to low soil nitrogen in West and Central Africa. African Crop Science Conference Proceedings Vol. 8. pp. 87-94

Azeez. J.O. and Adetunji. M.T. (2007). Nitrogen-use efficiency of maize genotypes under weed pressure in a tropical alfisol in Northern Nigeria. Tropicultura 25 (3): 174-I79.

Badu-Apraku. B. Menkir. A. Ajala. S. Akinwale. R. Oyekunle. M. and Obeng-Antwi. K. (2010). Performance of tropical earlymaturing maize cultivars in multiple stress environments. Canadian Journal of Plant Science Vol. 90:831-852.

Banziger M. Edmeades G O. Lafitte HR. 1999. Selection for drought tolerance increases maize yield across a range of nitrogen levels. Crop Sci 39: 1035-1040

Bänziger. M. Edmeades. G.O. Beck. D. and Bellon. M. 2000. Breeding for drought and nitrogen stress tolerance in maize: From theory to practice. Mexico. D.F. CIMMYT.

Bertin P. Gallais A (200I). Genetic variation for nitrogen use efficiency in a set of recombinant inbred lines. II. QTL detection and coincidences. Maydica 46:53-68.

Bertin. P \& Gallais. A. 2000. Physiological and genetic basis of nitrogen use efficiency in maize I. Agrophysiological results. Maydica 45-53-66.

Carsky RJ. Abaidoo R. Dashiell KE. Sanginga N (1997). Effect of soybean on subsequent maize grain yield in Guinea savanna of West Africa. Afr. Crop Sci. J. 5: 3I-39.

Carsky. R.J \& Iwuafor. E.N.O. 1999. Contribution of soil fertility research and maintenance to improve maize production and productivity in Sub-Saharan Africa. $\mathrm{Pp}$ 3-20.

Fakorede. M.A.B. Badu-Apraku. B. Kamara. A.Y. Menkir. A. and Ajala. S.O. (2003). Maize revolution in West and Central Africa: An overview. Proceedings of a Regional Maize Workshop. IITA-Cotonou. Republic of Benin. I4-I

FAO (200I). World Soil Resources Reports. p. 289.

Gondwe B.M., Mweetwa A.M., Munyinda K, Phiri E and Lungu $\mathrm{D}_{s}$. 2014 evaluation of maize genotypes for nitrogen use efficiency, maize genotypes and nitrogen use efficiency, Zambian Journal of Agricultural Science, Volume ro(I): 55-63

Hema D., Kim S. K., Mondeil F., Tio-Toure B. B., Tapsoba. A. 200I: Intervalle entre floraison mâle et femelle chez le maïs: son importance en sélection pour la tolérance à la sécheresse. Cahiers Agricultures Aout 200I, IO(4): p. 255-26o. 
H.R.LafitteG.O.EdmeadesS.Taba. I997. Adaptive strategies identified among tropical maize landraces for nitrogen-limited environments. Volume 49. Issues 2-3. February 1997. Pages I87-204

Iken. J.E. and Amusa. N.A. (2004). Maize research and production in Nigeria. African Journal of Biotechnology. 3(6). pp. 302-307.

Köppen W. 1936. Das geographische System der Klimate. In: Köppen W. \& H. Geiger (eds.). Handbuch der Klimatologie. Berlin.pp.I-44.

Lafitte. H.R. and Edmeades. G.O. I994a. Improvement for tolerance to low soil nitrogen in tropical maize. I. Selection criteria. Field Crops Res. 39. I-I4.

Lafitte. H.R. and Edmeades. G.O. I994b. Improvement for tolerance to low nitrogen in tropical maize. II. Grain yield. Biomass production and N accumulation. Field Crops Res. 39. 15-25.

Lafitte. H.R. and Edmeades. G.O. 1994c. Improvement for tolerance to low nitrogen in tropical maize. III. Variation in yield across environments. Field Crops Res. 39. 27-38.

Lafitte. H.R. and Edmeades. G.O. I994a. Improvement for tolerance to low soil nitrogen in tropical maize. I. Selection criteria. Field Crops Research 39:I-I4.

Menkir. A. Ajala. S.O. Kamara. A.Y. \& Meseka. S.K. 2006. Progress in breeding tropical maize for adaptation to suboptimal soil nitrogen at IITA. Paper presented at 42nd Illinois Corn Breeder's School. Champaign. Illinois. March 6 to 7. 2006.

Ogunniyan, D. J. Olakojo. S. A. 20I4. Genetic Variability of Agronomic Traits of Low Nitrogen Tolerant Open-Pollinated Maize Accessions as Parents for Top Cross Hybrids. Journal of Agriculture and Sustainability ISSN 220I-4357 Volume 6. Number 2. 2014. 179-196

Oikeh, SO.Chude VO. Kling JG. Horst W (2007). Comparative productivity of nitrogen-use efficient and nitrogen in-efficient maize cultivars and traditional grain sorghum in the moist savannas of West Africa. Afr. J. Agric. Res. 2(3): II2-II8.

Oikeh, S.O. 1996. Dynamics of soil nitrogen in cereal based cropping systems in the Nigerian savanna. Ph.D. dissertation. Ahmadu Bello University. Zaria. Nigeria. II94pp.

Tshiabukole, K. Khonde, P. Kankolongo. M. Jadika.T. Kasongo. K. Badibanga. M. Kasongo. T. and Vumilia. K. (2017) Suitable Hybrids and Synthetics Provitamin A Maize Selected for Release in the Democratic Republic of Congo. Open Access Library Journal. 4: e3446. https://doi.org/10.4236/ oalib.1103446 